\title{
Tumour Heterogeneity
}

Pathobiology

\section{Tumor Heterogeneity in Lymphomas: A Different Breed}

\author{
Christian M. Schürch ${ }^{a-c}$ Birgit Federmann ${ }^{a, b}$ Leticia Quintanilla-Martinez ${ }^{a, b}$ \\ Falko Fend ${ }^{a, b}$ \\ a Institute of Pathology and Neuropathology and ${ }^{b}$ Comprehensive Cancer Center, University Hospital Tübingen, \\ Tübingen, Germany; ' Institute of Pathology, University of Bern, Bern, Switzerland
}

\begin{abstract}
Keywords
Chronic lymphocytic leukemia/small lymphocytic lymphoma - Clonal evolution · Diffuse large B-cell lymphoma $\cdot$ Follicular lymphoma $\cdot$ Intratumoral heterogeneity · Lymphoma - Lymphoplasmacytic lymphoma - Mantle cell lymphoma - B-cell non-Hodgkin lymphoma Tumor heterogeneity
\end{abstract}

\begin{abstract}
The facts that cancer represents tissues consisting of heterogeneous neoplastic, as well as reactive, cell populations and that cancers of the same histotype may show profound differences in clinical behavior have long been recognized. With the advent of new technologies and the demands of precision medicine, the investigation of tumor heterogeneity has gained much interest. An understanding of intertumoral heterogeneity in patients with the same disease entity is necessary to optimally guide personalized treatment. In addition, increasing evidence indicates that different tumor areas or primary tumors and metastases in an individual patient can show significant intratumoral heterogeneity on different levels. This phenomenon can be driven by genomic instability, epigenetic events, the tumor microenvironment, and stochastic variations in cellular function and antitumor-
\end{abstract}

al therapies. These mechanisms may lead to branched subclonal evolution from a common progenitor clone, resulting in spatial variation between different tumor sites, disease progression, and treatment resistance. This review addresses tumor heterogeneity in lymphomas from a pathologist's viewpoint. The relationship between morphologic, immunophenotypic, and genetic heterogeneity is exemplified in different lymphoma entities and reviewed in the context of high-grade transformation and transdifferentiation. In addition, factors driving heterogeneity, as well as clinical and therapeutic implications of lymphoma heterogeneity, will be discussed.

(c) 2017 S. Karger AG, Basel

\section{Introduction}

Tumor heterogeneity is a phenomenon that has long been recognized by pathologists, cancer researchers, and medical oncologists. Tumor heterogeneity can conceptually be divided into intertumoral and intratumoral heterogeneity. Intertumoral heterogeneity describes the variability in morphology, immunophenotypes, genetic aberrations, epigenetic events, therapy responses, and clinical outcomes of distinct tumor entities in different

\section{KARGER}

(C) 2017 S. Karger AG, Basel

E-Mail karger@karger.com

www.karger.com/pat
Falko Fend

Institute of Pathology and Neuropathology, University Hospital Tübingen

Liebermeisterstrasse 8

DE-72076 Tübingen (Germany)

E-Mail falko.fend@med.uni-tuebingen.de 
patients. In contrast, intratumoral heterogeneity designates the variability of individual tumor cells and tumor subclones within the complex and dynamic ecosystem of a given neoplasm in a single patient [1-6]. Intratumoral heterogeneity can be influenced by the interactions of cancer cells with other cancer cells (clonal cooperativity/competition) [7] and of cancer cells with cells and structures of the tumor microenvironment (i.e., immune cells, vasculature, cancer-associated fibroblasts, and extracellular matrix), by tissue oxygenation, $\mathrm{pH}$, and nutrient availability, and by stochastic variation in cellular function. Intratumoral heterogeneity also describes the divergence between primary tumor and metastatic sites as well as temporal heterogeneity depending on the point of analysis of primary versus recurrent tumors $[1-3,6]$.

The concepts on the origins of intratumoral heterogeneity were extensively discussed already more than 30 years ago [8]. At that time, evidence for intratumoral heterogeneity was mostly obtained in cell lines or animal experiments and was only indirectly observed in human cancers. In recent years, however, the field of tumor heterogeneity has witnessed unprecedented advances due to new genetic and computational technologies that enable massive parallel DNA sequencing to study cancer genomes at a large scale. These efforts have revealed an intriguing inter- and intratumoral genetic heterogeneity in a wide variety of malignancies including lymphomas and they have had a considerable impact on cancer diagnostics and treatment $[1-3,9]$. In addition, genetic heterogeneity has been shown to influence disease progression and outcomes as well as the response to therapy [10-12]. Besides genetic heterogeneity, processes that are not readily analyzable by genome or exome sequencing, such as DNA methylation, histone modification, micro-RNA and noncoding RNA, and tumor cell phenotype, as well as the interactions between tumor cells and the microenvironment, may play important roles in functional heterogeneity [3]. Further layers of complexity are introduced by the hierarchical organization of some tumors into a bulk of malignant cells and so-called cancer stem cells that have the ability to self-renew and thereby pose a reservoir for long-term maintenance of malignant growth [13].

In this review, we will focus on tumor heterogeneity in lymphomas, emphasizing morphologic, immunophenotypic, and genetic heterogeneity; intratumoral heterogeneity and subclonal evolution; and transformation and transdifferentiation, as well as clinical and therapeutic aspects. Further investigation into lymphoma heterogene-

Lymphoma Heterogeneity ity will allow a more precise diagnosis and treatment of individual patients' diseases and it will pave the way towards highly personalized lymphoma management.

\section{Malignant Lymphomas Mirror the Complexity of the Immune System}

In the 2016 updated 4th edition of the World Health Organization (WHO) classification of tumors of hematopoietic and lymphoid tissues, more than 90 different categories of B-and T-cell lymphomas are distinguished $[14,15]$. This complex classification, which tries to group lymphomas according to their putative cell of origin, as well as their clinical and pathological features, reflects our deepening understanding of the immune system, with different lymphocyte subsets undergoing complex maturation steps and each step potentially having malignant counterparts. The precise classification of a patient's lymphoma is crucial to predict the clinical course (from indolent to aggressive) and to guide the choice of treatment regimen, from "watch and wait" to multimodal (radio-, immuno-, chemo-) therapy [16-19]. Histomorphologic and cytologic analyses of the growth pattern, tissue architecture, cell size, nuclear features, and reactive microenvironment of a given tumor by microscopy of stained tissue slides are still the most important tools for establishing a diagnosis of lymphoma. Ancillary studies, such as immunohistochemistry and sometimes molecular testing, are required to confirm the diagnosis and to further classify the entity for prognostic and predictive purposes.

\section{Intratumoral Heterogeneity in Lymphoma}

Lymphomas in individual patients can exhibit different types of intratumoral heterogeneity (Table 1), and this phenomenon is often of prognostic and predictive importance. In a proportion of patients, 2 distinct lymphoma entities as defined by the WHO criteria can be diagnosed either at different time points of the disease or simultaneously at the first diagnosis in the same organ or in different organs, such as lymph nodes (LN) and bone marrow (BM). Irrespectively of the setting, it is of major importance to investigate - usually by studying clonal immunoglobulin or T-cell receptor rearrangements whether intratumoral heterogeneity is the result of evolution of the neoplastic clone or indicates the presence of a second, clonally unrelated neoplasm [20]. 
Table 1. Definitions

\begin{tabular}{ll}
\hline Composite lymphoma & $\begin{array}{l}\text { Example of intratumoral heterogeneity; a lymphoma that consists of at least } 2 \text { different entities that occur } \\
\text { simultaneously in the same organ ("collision tumor") }\end{array}$ \\
\hline Concordant involvement & BM (or other organ) infiltration by the same lymphoma entity \\
\hline Discordant lymphoma & $\begin{array}{l}\text { Example of spatial heterogeneity; occurrence of 2 histologically distinct lymphoma types in } 2 \text { different } \\
\text { anatomical locations; most often observed as high-grade lymphoma in a lymph node with discordant BM } \\
\text { involvement by a low-grade lymphoma }\end{array}$ \\
\hline Gray zone lymphomas & $\begin{array}{l}\text { High-grade lymphomas that display overlapping or borderline morphologic, immunophenotypic, and } \\
\text { biological features between different lymphoma entities and therefore cannot be unequivocally catego- } \\
\text { rized [36, 37] }\end{array}$ \\
\hline Relapse & $\begin{array}{l}\text { Recurrence of a morphologically identical lymphoma after therapy; most often clonally related, some- } \\
\text { times clonally unrelated [61]; thought to arise from a common lymphoma progenitor through linear or } \\
\text { branched evolution in clonally related cases }\end{array}$ \\
\hline Transdifferentiation & $\begin{array}{l}\text { Example of intratumoral heterogeneity; presence of a myeloid neoplasm (most often histiocytic/dendritic } \\
\text { cell sarcoma) in a lymphoma patient, hypothesized to derive from the lymphoma clone or a CPC based } \\
\text { on the demonstration of identical gene rearrangements, mutations, or chromosomal translocations in } \\
\text { both tumor components }\end{array}$ \\
$\begin{array}{l}\text { Example of temporal heterogeneity; progression of a low-grade lymphoma into a high-grade lymphoma } \\
\text { (usually DLBCL; less commonly lymphoblastic lymphoma, Burkitt lymphoma, PBL, BCL-U, or CHL) } \\
\text { during the disease course; known as Richter's syndrome in CLL; transformation is associated with treat- } \\
\text { ment resistance, clinical disease progression, and increased disease-specific mortality; cooccurrence of } \\
\text { transformed lymphoma is not considered composite lymphoma }\end{array}$ \\
\hline Transformation
\end{tabular}

$\mathrm{BM}$, bone marrow; CPC, common progenitor cell/clone; DLBCL, diffuse large B-cell lymphoma; PBL, plasmablastic lymphoma; BCL-U, B-cell lymphoma, unclassified; CHL, classical Hodgkin lymphoma; CLL, chronic lymphocytic leukemia.

The most common example of intratumoral heterogeneity is the evolution of a low-grade lymphoma into a high-grade lymphoma during the disease course, known as lymphoma transformation (Fig. 1). Transformation, considered to represent clonal evolution, is usually associated with clinical disease progression and an adverse outcome [21]. In chronic lymphocytic leukemia/small lymphocytic lymphoma (CLL/SLL), high-grade transformation into diffuse large B-cell lymphoma (DLBCL) is known as Richter's syndrome (RS) and occurs in up to $10 \%$ of patients, with an estimated transformation rate of $0.5-1 \%$ per year [22]. Of note, $10-20 \%$ of DLBCL in patients with CLL/SLL are clonally unrelated to the CLL/ SLL. These patients show a superior prognosis compared to true, clonally related RS [23-25]. Rarely, CLL/SLL, as well as other B-cell non-Hodgkin lymphomas (B-NHL), may transform into classical Hodgkin lymphoma (HL). For the cases of classical HL, which are frequently Epstein-Barr virus positive, determination of clonal relationship is very difficult for technical reasons, but several studies using single-cell analysis have demonstrated that classical HL in the setting of CLL/SLL and other indolent
B-NHL may be both clonally related and clonally unrelated (Fig. 2) [26, 27]. The 10-year risk of transformation in follicular lymphoma (FL), the most frequent low-grade B-NHL, ranges between 15 and $20 \%$, with an annual transformation rate of about 2-3\% [28]. Marginal zone lymphoma transforms into high-grade lymphoma in 10 $14 \%$ of patients over time, although the true incidence rates of transformation are poorly documented [21].

Secondly and less frequently, patients are simultaneously diagnosed with a low-grade and a high-grade lym-

Fig. 1. Types and genetic mechanisms of transformation. Common low-grade lymphomas and their transformed counterparts are depicted. Percentages indicate the frequency of the type of transformation, according to Agbay et al. [21], Parikh et al. [22], and Montoto and Fitzgibbon [28]. CLL/SLL, chronic lymphocytic leukemia/small lymphocytic lymphoma; FL, follicular lymphoma; MZL, marginal zone lymphoma; LPL, lymphoplasmacytic lymphoma; DLBCL, diffuse large B-cell lymphoma; HL, Hodgkin lymphoma; PBL, plasmablastic lymphoma; BCL-U, B-cell lymphoma, unclassified; B-ALL, B-cell acute lymphoblastic leukemia; BL, Burkitt lymphoma.

(For figure see next page.) 


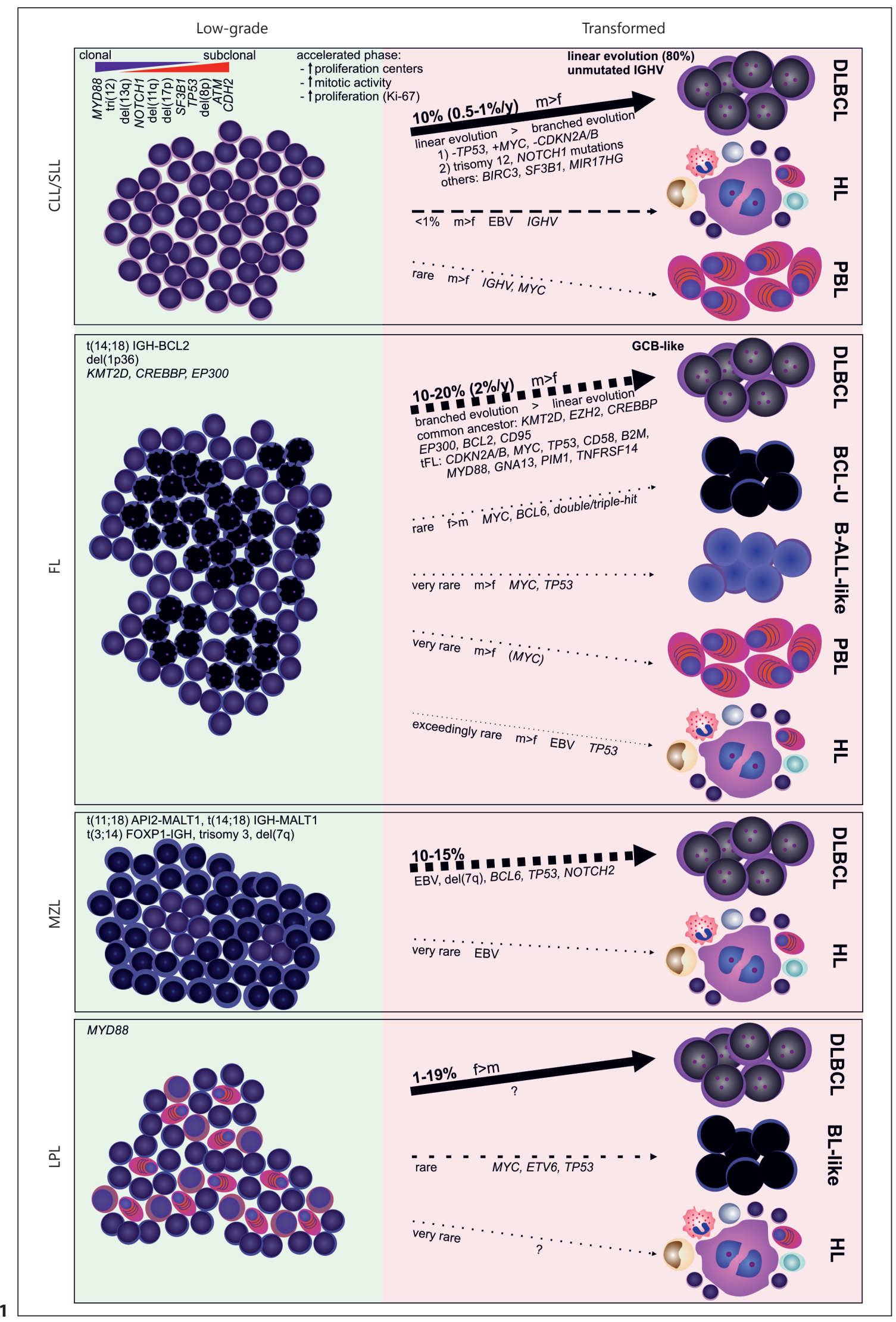


phoma at different anatomical sites. This spatial form of intratumoral heterogeneity, known as discordant involvement, occurs in 5-7\% of patients according to recent studies [29-31] and most often presents as DLBCL in an LN with discordant low-grade lymphoma infiltration in the BM [20]. In patients with a low-grade and a highgrade component at different sites, it is of major importance to investigate the clonal relationship between the 2 components. Kremer et al. [32] demonstrated that in DLBCL patients a significant fraction of cases with discordant BM involvement harbors clonally unrelated secondary low-grade B-cell neoplasms such as monoclonal B-cell lymphocytosis or CLL/SLL. Furthermore, a third corresponded to reactive lymphoid infiltrates. These facts may contribute to the superior survival of patients with discordant as compared to concordant BM involvement in DLBCL.

Thirdly and least frequently, 2 different, usually clonally unrelated lymphoma entities coincide within the same organ, presenting as a "collision tumor" known as a composite lymphoma. Composite lymphomas, intriguing examples of intratumoral heterogeneity, consist of either 2 separate B-NHL (Fig. 3) or a combination of BNHL and HL and occur in only $1-4 \%$ of lymphoma patients $[33,34]$. Rarely, classical HL collides with nodular lymphocyte-predominant HL [35]. In composite lymphomas, tumor borders can be clearly defined, or tumor cells can be partly intermixed. Composite lymphomas should not be confounded with the so-called gray zone lymphomas, which are high-grade lymphomas that display overlapping or borderline morphologic, immunophenotypic, and biological features between different lymphoma entities and therefore cannot be unequivocally categorized [36, 37].

In addition, some low-grade lymphoma subtypes show a topographically defined morphologic and immunophenotypic intratumoral heterogeneity. For example, tumor cells in the proliferation centers of CLL/SLL are of a larger size, exhibit an increased proliferation rate as analyzed by Ki-67 immunohistochemistry, and upregulate several antigens. In FL, tumor cells outside of the neoplastic follicles often downregulate CD10 and BCL6. Phenotypic and sometimes morphologic heterogeneity is also observed in different tumor compartments, e.g., between $\mathrm{BM}$ and LN or LN and peripheral blood [38-42]. Further aspects of morphologic heterogeneity can be found in lymphomas that display maturation towards plasma cells, such as lymphoplasmacytic lymphoma. Lymphoplasmacytic lymphoma can demonstrate a high intertumoral and intratumoral heterogeneity in terms of plasma cell maturation, with some patients showing nearly no maturation (only small lymphocytic cells) and other patients showing a high degree of maturation towards plasma cells [43]. Importantly, after treatment with the anti-CD20 monoclonal antibody rituximab, the loss of the lymphoid tumor component can be so dramatic that a misdiagnosis of plasma cell neoplasm might occur $[44,45]$.

\section{Genetic Intratumoral Heterogeneity, Clonal Evolution, and Transformation}

Recent seminal studies addressing intratumoral genetic heterogeneity and mechanisms of transformation in low-grade lymphomas have revealed highly interesting and important results that may change the clinical practice in the near future.

CLL/SLL is an incurable neoplasm consisting of mature, small B cells that grow diffusely and express surface CD20, CD23, and CD5 and nuclear LEF1. Despite its apparently homogeneous appearance and phenotype, which is stable among patients, CLL/SLL is clinically a highly heterogeneous disease that rapidly progresses in some patients while being indolent without indication for therapy for decades in others [46]. This heterogeneity of CLL is based on a variety of clinical, phenotypic, and genetic parameters, which have led to the development of advanced biological prognostic scores [47]. However, intratumoral heterogeneity in CLL adds another layer of complexity, and recent seminal work by Landau et al. [12] has shed light on the underlying mechanisms. Studying 149 CLL/ SLL patients by whole-exome sequencing, they found that driver mutations in CLL/SLL can be divided into predominantly clonal (e.g., MYD88, trisomy 12, and $\operatorname{del}[13 q]$ ), clonal and subclonal (e.g., del[11q], del[17p], and SF3B1), or predominantly subclonal (e.g., TP53, $A T M$, and CDH2) (Fig. 1) [12]. When analyzing patients at different time points, they found that 10 of 12 patients receiving chemotherapy underwent clonal evolution originating from subclones with driver mutations that expanded over time. In contrast, this phenomenon was only observed in 1 of 6 patients without treatment. They hypothesized that chemotherapy leads to 2 different scenarios in CLL/SLL depending on the presence or absence of subclonal driver mutations. If subclonal driver mutations are absent, chemotherapy leads to a balanced reduction of all malignant clones (clonal equilibrium). In contrast, the presence of aggressive subclones harboring driver mutations (which may be "controlled" by clonal competition in untreated patients) may be unmasked and selected 

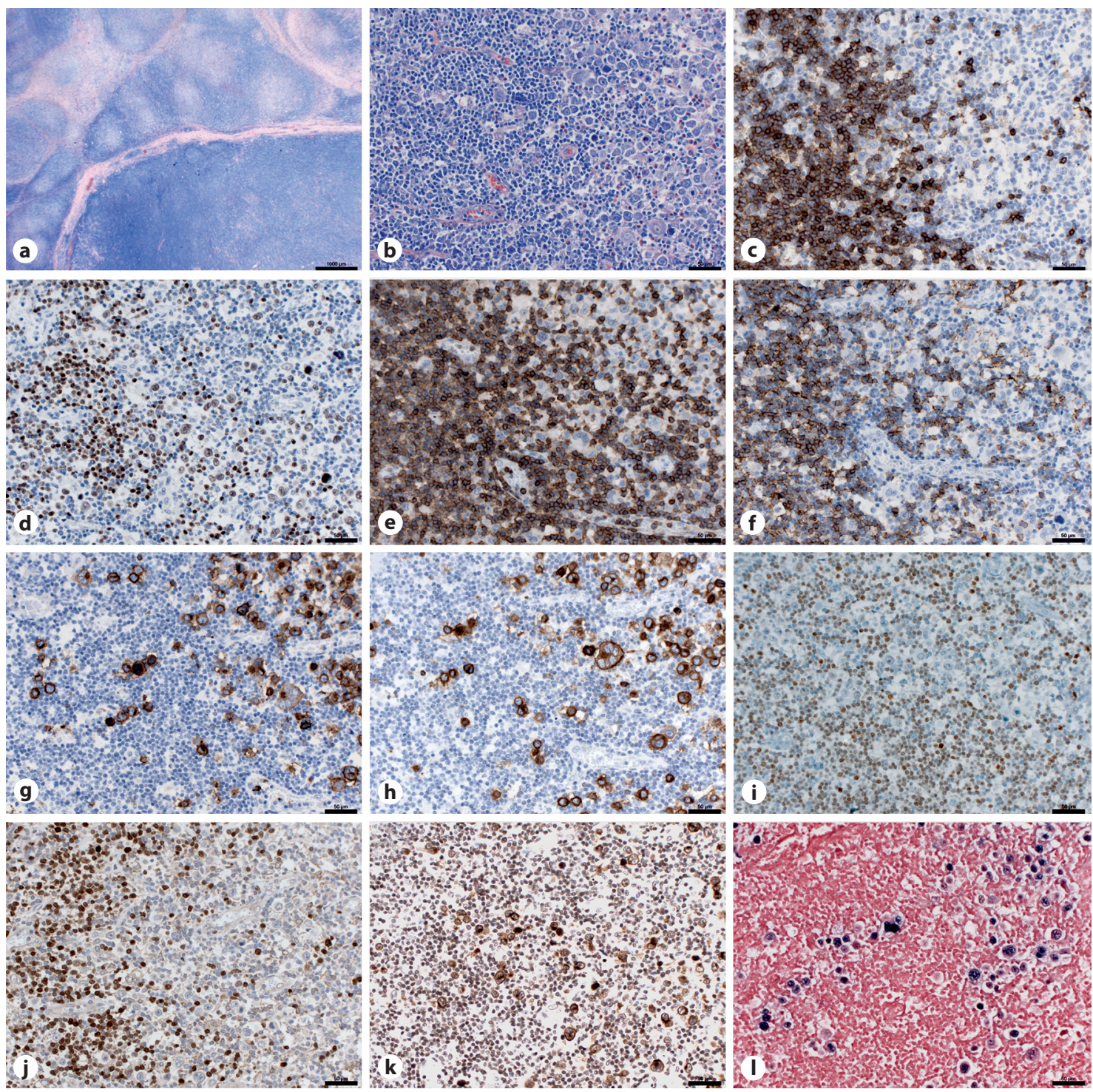

Fig. 2. Nodular sclerosis classical Hodgkin lymphoma transformation of chronic lymphocytic leukemia/small lymphocytic lympho$\mathrm{ma}$ (CLL/SLL). The clonal relationship was not tested in this case. a Scanning magnification shows an enlarged lymph node subdivided into large nodules by broad fibrous septa. Some darker, diffuse areas and lighter nodules are seen (Giemsa stain). b Cytologically, at the border of the darker areas with lighter nodules, there is an admixture of small, round CLL/SLL lymphocytes with large Hodgkin and Reed-Sternberg cells (Giemsa stain). c Immunohistochemically, CD20 is positive in the CLL/SLL area (left) and shows the typical negativity in the Hodgkin and Reed-Sternberg cells (right). d PAX5 is strongly nuclear positive in the CLL/SLL cells and has less staining intensity in the Hodgkin and Reed-
Sternberg cells, consistent with shutdown of the B-cell gene expression programs in these cells. e Staining for CD5 shows positivity in the CLL/SLL cells (left) and an abundant infiltrate of reactive $\mathrm{T}$ lymphocytes (CD3, not shown) intermixed with the Hodgkin and Reed-Sternberg cells (right). f CD23 marks the CLL/SLL cells. CD15 (g) and CD30 (h) are strongly positive in the Hodgkin and Reed-Sternberg cells. OCT2 (i) and BOB1 (j) show nuclear positivity in the CLL/SLL cells and are negative in the Hodgkin and ReedSternberg cells. LMP1 (k) and Epstein-Barr virus (I) mRNA in situ hybridization (EBER) are positive in the Hodgkin and Reed-Sternberg cells, consistent with Epstein-Barr virus infection. Magnifications: $\times 12.5$ (scale bar, 1,000 $\mu \mathrm{m})(\mathbf{a})$ and $\times 200(\mathbf{b}-\mathbf{I})($ scale bars, 50 $\mu \mathrm{m})$. 


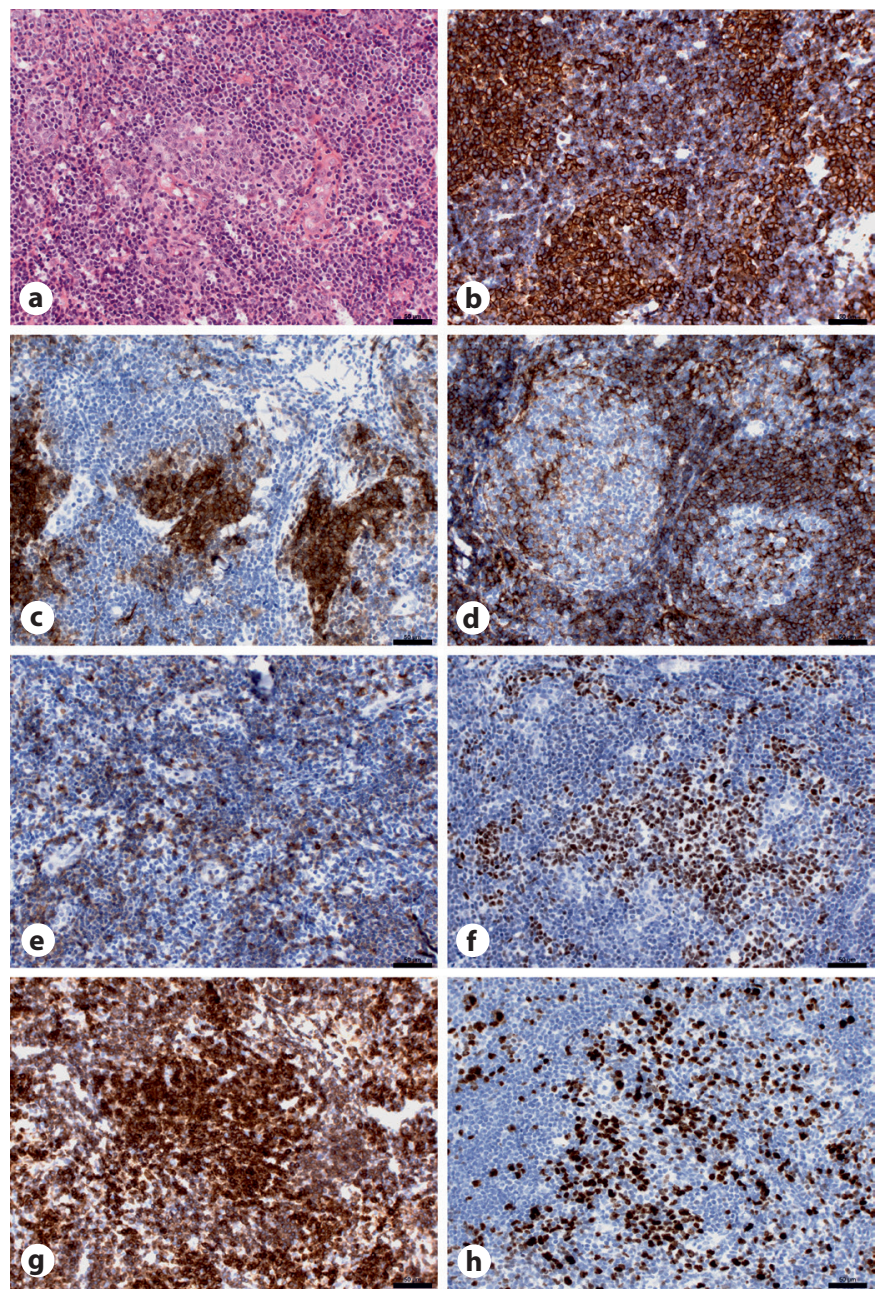

Fig. 3. Example of a composite lymphoma consisting of chronic lymphocytic leukemia/small lymphocytic lymphoma (CLL/SLL) admixed with follicular lymphoma (FL). a The H\&E stain shows a lymphatic infiltrate that has a partly diffuse and partly nodular growth pattern with germinal center-like structures. Cytologically, the cells in the diffuse areas are small, round lymphocytes with little cytoplasm and dense nuclear chromatin, corresponding to CLL/SLL. In contrast, the cells in the nodules are medium sized centrocytes with angular nuclei, rather open chromatin, and ample cytoplasm with some larger, interspersed centroblasts, corresponding to FL. b CD20 staining shows diffuse positivity in all cells with strong staining intensity in the FL nodules and a weaker intensity in the diffuse CLL/SLL areas. c CD10 is positive in the nodular areas. $\mathbf{d}$ CD23 stains the diffuse areas and marks some follicular dendritic cells within the nodules. e CD5 is weakly positive in the diffuse areas and strongly stains the T lymphocytes (CD3, not shown). $\mathbf{f}$ BCL6 is positive in the nodules. $\mathbf{g}$ BCL2 shows a pattern similar to CD20 with 2 staining intensities. $\mathbf{h}$ The proliferation rate (Ki-67) is low in the diffuse areas $(\sim 5 \%)$ and higher in the nodules $(\sim 30 \%)$. All magnifications: $\times 200$ (scale bars, $50 \mu \mathrm{m})$. for by chemotherapy, resulting in clonal outgrowth and disease progression [12]. These findings were confirmed and extended in a more recent study by the same group that included a total of 538 CLL/SLL patients of whom 278 were prospectively recruited [48]. Importantly, some of the subclonal driver mutations described by Landau et al. [48] (TP53 loss or del[17p], mutations in NOTCH1 or SF3B1) are implicated in the pathogenesis of RS, along with additional genetic events (MYC amplification, $C D K N 2 A / B$ loss, and tri[12]) $[49,50]$. Based on their findings that TP53 and/or CDKN2A/B inactivation were mutually exclusive with tri(12), Chigrinova et al. [49] proposed that RS may evolve via 2 main genetic pathways, i.e., (1) TP53 inactivation, MYC activation, and $C D K N 2 A / B$ loss and (2) tri(12) followed by NOTCH1 mutation (Fig. 1) These findings were independently confirmed by Fabbri et al. [50], who proposed a linear evolution model for CLL/SLL transformation into RS and demonstrated that the genetic landscape in RS-DLBCL is substantially different from that of de novo DLBCL. This provides an explanation for the different disease biology, the higher aggressiveness, and the much poorer outcome of RS-DLBCL compared to de novo DLBCL [23-25].

Like CLL/SLL, FL is an incurable malignancy that most often presents as a low-grade tumor (grade 1-2) consisting of small neoplastic B cells with a follicular growth pattern. FL harbors an inherent risk of high-grade transformation with an annual incidence of $2-3 \%$. In contrast to CLL/SLL, which is believed to evolve linearly, the current hypothesis for transformed FL ( $\mathrm{tFL}$ ) is derivation from a long-lived common progenitor cell/clone (CPC). Okosun et al. [51] sequenced 10 FL-tFL sample pairs and identified 2 distinct patterns of evolution, which they coined "rich" and "sparse" CPC. In 8 patients undergoing evolution along the "rich" CPC pathway, FL and tFL samples showed a high clonal semblance, and CPC harbored many mutations previously reported in DLB$\mathrm{CL}$, such as in histone modifiers (KMT2D, CREBBP, $E P 300, E Z H 2$, and $M E F 2 B$ ), immune genes (B2M, CD58, and TNFRSF14), JAK-STAT signaling (SOCS1 and STAT6), and B-cell receptor-signaling genes (BCL10, $C A R D 11$, and $C D 79 B)$. Conversely, in 2 patients, only 4 nonsynonymous mutations were shared by the FL and tFL samples ("sparse" CPC). Importantly, the FL and tFL clones in these 2 cases independently acquired different mutations in KMT2D, TNFRSF14, and CREBBP, indicating that these genes play a very important role in FL lymphomagenesis and transformation. Furthermore, by performing deep sequencing of 28 selected genes in an extension cohort, those authors could demonstrate
Schürch/Federmann/QuintanillaMartinez/Fend 
intratumoral heterogeneity in FL in analogy to CLL/SLL. Clonal mutations were mostly observed in early event genes such as KMT2D, CREBBP, EZH2, STAT6, and TNFRSF14, whereas subclonal mutations were observed in genes that were associated with transformation, like MYD88, EBF1, and TNFAIP3 [51]. In line with these findings, a divergent pattern of evolution from an ancestor CPC was observed in 10 of 12 FL-tFL sample pairs studied by Pasqualucci et al. [52]. Linear evolution from a minor subclone that harbored tFL-specific mutations and was already present in the diagnostic FL sample was demonstrated in 2 patients. Importantly, this study confirmed and extended the findings of Okosun et al. [51] regarding important genes involved in FL pathogenesis and transformation (KMT2D, CREBBP, EZH2, FAS, BCL2, TP53, $M Y C, C D K N 2 A / B, B 2 M$, and PIM1). Furthermore, these analyses revealed a marked genomic instability in tFL compared to FL and other lymphoid neoplasms [52]. In analogy to the subclonal heterogeneity of CLL/SLL [12], Green et al. [53] found that the majority of mutations in their $8 \mathrm{FL}$ samples corresponded to minor subclonal mutations that were heterozygous, with the exception of homozygous CREBBP and KMT2D mutations that were most likely clonal. Studying 2 samples with matched relapsed FL, those authors proposed an elegant genetic evolution model for (nontransformed) FL that is based on founder mutations (e.g., BCL2), leading to a premalignant tumor cell population ("CPC") stable enough to acquire further genetic events. This is followed by driver mutations in the progenitor clone (e.g., CREBBP) that lead to an early malignant clone that may acquire further accelerator mutations (e.g., KMT2D and TNFRSF14) during the pathway of disease progression [53].

\section{Intertumoral and Intratumoral Heterogeneity beyond Histopathological Classification: the Example of DLBCL}

DLBCL, the most frequent B-NHL in adults, is clinically heterogeneous in terms of treatment response and long-term outcome. The molecular basis of this heterogeneity was first characterized by Alizadeh et al. [54], who studied the cell-of-origin phenotype by DNA microarrays and identified distinct gene expression profiles related to germinal center B-cell (GCB) or activated B-cell types. A further layer of complexity was introduced by Lenz et al. [55], who identified signatures of the tumor microenvironment that are associated with survival. However, because these technologies are very costly and time consuming, they have not been implemented in the daily routine pathological diagnostics of DLBCL. Since the many DLBCL subtypes cannot readily be identified based on morphology alone, each case of suspected DLBCL requires a more or less extensive immunohistochemical workup to be correctly classified for prognostic and predictive purposes. Hence, we use antibodies against CD20 and CD3 to establish the cell lineage (with CD20 also being predictive for rituximab treatment); CD10, BCL6, MUM1, CD30, and CD5 to assess prognostic immunohistochemical cell-of-origin subgroups (GCB vs. non-GCB type; $\mathrm{CD}^{+}$type; and $\mathrm{CD} 30$ expression); and the expression of MYC and BCL2 proteins (doubleexpressers with $\geq 40 \%$ MYC- and $\geq 50 \%$ BCL2-positive cells, respectively, that are associated with a worse prognosis) and Ki-67 to address cell proliferation [56]. The Hans classifier using CD10, BCL6, and MUM1 is the most widely used immunohistochemical surrogate marker for the molecular cell-of-origin subgroups of GCB versus activated B-cell DLBCL types that was recently validated using NanoString ${ }^{\circledR}$ technology $[54,57,58]$. Other, less commonly used, classifiers include Visco-Young, Choi, Muris, Nyman, and Tally, some of which implement additional antibodies such as FOXP1, GCET1, BCL2, and LMO2 [56]. All classifiers have their advantages and disadvantages and can complement each other in the classification of difficult cases. Intertumoral heterogeneity in DLBCL can thus readily be examined by pathologists and exemplifies a clinically important basis for prognosis and probably in the future also for treatment decisions. Although subtyping of DLBCL according to the GCB versus non-GCB is recommended in the 2016 updated version of the WHO classification [15], it is not yet clear which method or algorithm is the best to address this distinction for clinical purposes. Similarly, there is currently no accepted selection strategy to identify cases of high-grade B-cell lymphoma carrying translocations of $M Y C$ with $B C L-2$ and/or BCL-6, so-called double- or triple-hit lymphomas, which need to be recognized according to the 2016 updated WHO classification [15, 59]. Nevertheless, double- or triple-hit lymphomas are concentrated in the GCB type, whereas double-expressers are concentrated in the non-GCB group.

In contrast to the long-recognized intertumoral heterogeneity in DLBCL, which is now implemented in daily diagnostics as outlined above, intratumoral heterogeneity in DLBCL is only beginning to be understood. A promising strategy to investigate DLBCL intratumoral heterogeneity is the genetic comparison of paired samples at first diagnosis and relapse. In doing so by deep se- 
quencing the variable, diversity, and joining regions of the immunoglobulin heavy chain in tumors from 14 relapsed patients, Jiang et al. [60] discovered 2 distinct evolutionary scenarios of DLBCL. They could show that diagnosis and relapse tumors are clonally related, and characterization of somatic hypermutation patterns allowed the identification of unique subclones. Phylogenetic analysis of these subclones revealed that the major subclone at diagnosis and relapse either had very different somatic hypermutation patterns (early divergence) or clustered together very closely (late divergence). The authors hypothesized that in the early divergence mode of clonal evolution, diagnosis and relapse clones develop in parallel, whereas in the late divergence mode relapse clones develop directly from the diagnosis clone. In addition, by targeted ultradeep resequencing and exome sequencing, they could demonstrate recurrent mutations in epigenetic modifiers such as EP300, KMT2D, and SETDB1 in both diagnosis and relapse clones, as well as mutations in immune surveillance genes, such as CD58 and IL9R in relapse clones. This indicates that epigenetic modifiers are real driver mutations in DLBCL and that the failure of immune surveillance contributes to disease relapse [60]. Similar conclusions were drawn by Juskevicius et al. [61], who also identified 3 clonally unrelated relapses in their cohort of 20 paired diagnosis-relapse samples.

Mutations in epigenetic modifiers are frequent in DLBCL [62]; however, the contribution of epigenomic alterations to tumor evolution is poorly understood. In an attempt to characterize the epigenome of DLBCL during disease progression, Pan et al. [63] performed genomewide DNA methylation profiling in 13 diagnosis-relapse sample pairs at single base pair resolution. They found heterogeneous evolution of DLBCL methylomes and identified a relapse-associated methylation signature enriched in key cellular pathways such as transforming growth factor- $\beta$ signaling and antiapoptotic pathways. Importantly, the current standard treatment regimen for DLBCL (RCHOP; rituximab, cyclophosphamide, doxorubicin, vincristine, and prednisolone) does not seem to be linked to direct effects on DNA methylation or epigenetic modifiers, favoring the conclusion that epigenomic alterations are disease-intrinsic mechanisms of relapse [63].

\section{Transdifferentiation}

In recent years, accumulating case reports have demonstrated the cooccurrence of lymphoid and myeloid lineage neoplasms with a clonal relationship. An example of transdifferentiation is shown in Figure 4. Reported cases include histiocytic/dendritic cell (H/DC) neoplasms in patients suffering from low-grade B-cell lymphomas, such as FL, Mantle cell lymphoma, hairy cell leukemia, or CLL/SLL [64], as well as Langerhans cell neoplasms in patients with lymphoblastic leukemia/lymphoma of either B-cell (B-LBL) [65] or T-cell (T-LBL) [66] origin (Table 2). Myeloid differentiation in a low-grade lymphoma patient sample may pose diagnostic problems because of a morphologic resemblance to large cell lymphoma, mimicking transformation. In the cases reported in the literature, myeloid cell differentiation was suspected based on morphology (cells with abundant eosinophilic cytoplasm, spindle cells, and whorled growth pattern) but it was often confirmed after extensive an immunohistochemical workup using markers like CD34, CD43, CD33, CD68, CD163, lysozyme, S100, CD1a, and CD207. Therefore, though a very rare event, we suspect that the incidence of myeloid differentiation in lymphomas is likely underestimated because of diagnostic difficulty and the lack of appropriate immunohistochemical and molecular methodologies for its identification. Mechanistically, there are several models that may explain the cooccurrence of a lymphoid and a myeloid neoplasm in the same patient. Firstly, it could be a coincidence of 2 clonally unrelated neoplasms (de novo H/DC neoplasm). Secondly, both lymphoma and H/DC neoplasm could arise from an immature CPC, because normal mature hematopoietic cells originate from multipotent hematopoietic stem cells that differentiate via oligopotent precursor cells along either the myeloid or the lymphoid lineages [67]. Thirdly, plasticity between lymphoid and myeloid cells could be explained by dedifferentiation of lymphoid cells towards more immature cell types, followed by differentiation along the myeloid lineage. And fourthly, lymphoid cells may directly transdifferentiate into myeloid cells. This latter hypothesis is supported by experimental models mainly used by Graf and colleagues, demonstrating that committed T-cell progenitors and B-cell lymphoma/ leukemia cells can be effectively transdifferentiated into myeloid cells by overexpression of SPL1 (PU.1) and/or $C E B P A$ transcription factors [68-70]. In addition, Wang et al. [71, 72] found hypermutation in IGVH loci in the H/DC neoplasm component in 2 patients harboring lowgrade lymphomas. This strongly suggests derivation from a mature $B$ cell that underwent somatic hypermutation in the LN germinal center reaction $[71,72]$. A seminal study by Feldman et al. [73] investigated 8 patients with FL and syn- or metachronous H/DC neoplasm, a clonal relation which was proven by demonstration of identical $t(14 ; 18)$ 

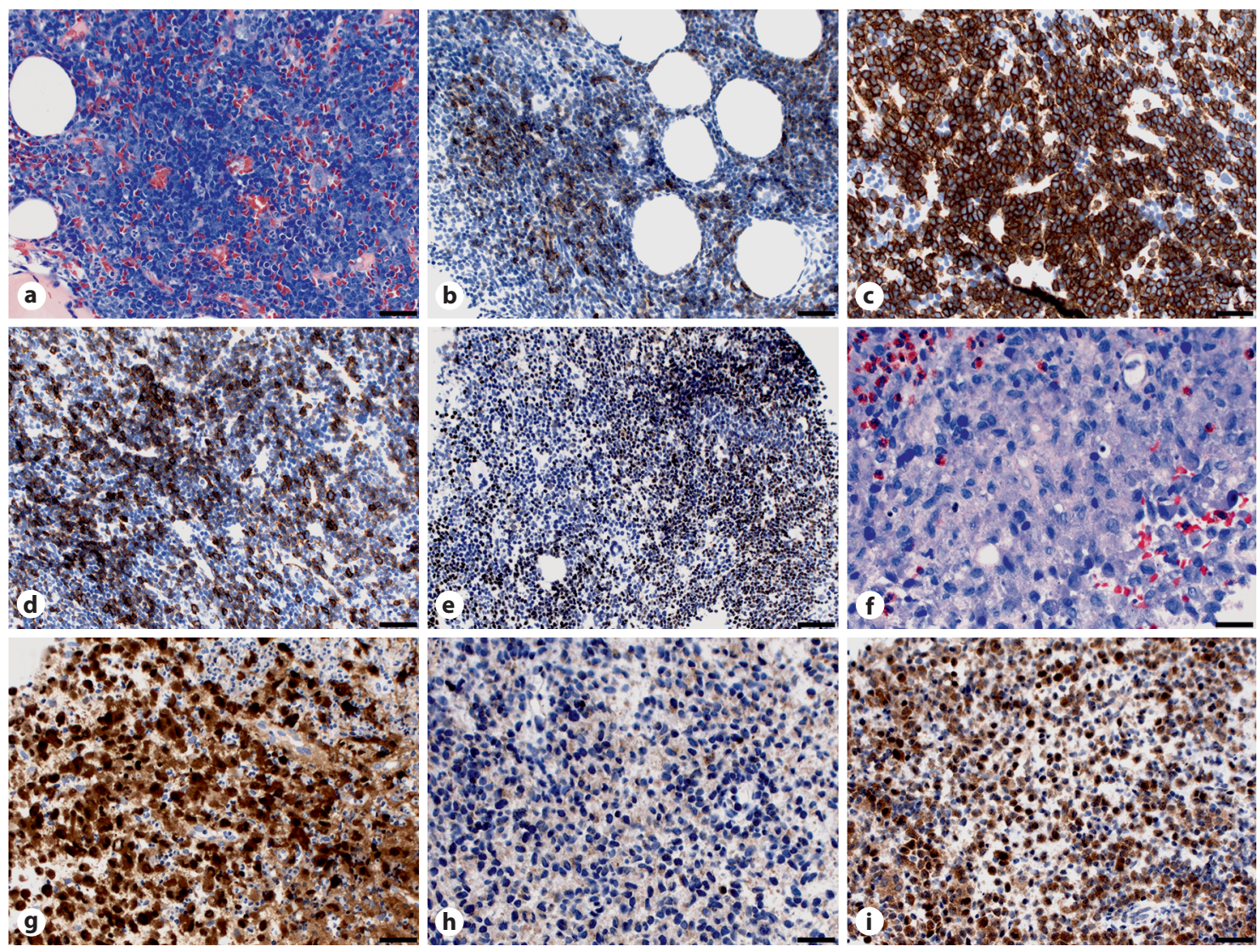

Fig. 4. Example of transdifferentiation of chronic lymphocytic leukemia/small lymphocytic lymphoma (CLL/SLL) to Langerhans cell histiocytosis (LCH). a Bone marrow (BM) infiltration by small, round lymphocytes with little cytoplasm and dense nuclear chromatin, corresponding to CLL/SLL (Giemsa stain). Immunohistochemically, the CLL/SLL cells are weakly positive for CD20 (b) and strongly positive for CD5 (c), and they show intermediate positivity for CD23 (d) and positivity for PAX5 (e). In the femur of the same patient, radiological imaging revealed a mass that was suspicious for high-grade transformation. f An excisional biopsy was performed, which showed large polygonal cells with histiocytic morphology, abundant eosinophilic cytoplasm, and bean-shaped nuclei. These cells were positive for S-100 (g) as well as CD1a (not depicted) and negative for PAX5 (h). i Staining with an antibody specific for the BRAF V600E mutation was positive. Molecular analyses revealed identical IGH rearrangements and TP53 mutations in both the CLL/SLL and the LCH tumors. The LCH component exhibited an additional BRAF V600E mutation, which was absent in the CLL/SLL component. translocations and IGH rearrangements in both FL and H/DC clones. They postulated that the H/DC tumor arises from either a differentiated FL cell or a CPC at least at the pre-B-cell stage of differentiation. In contrast, Buser et al. [74], who analyzed a compound pro-T LBL and indeterminate dendritic cell tumor simultaneously occurring at 3 different anatomical sites in a 59-year-old woman, found a tri(21) in both tumor components, whereas only the pro-T LBL additionally contained a monosomy(18) and NRAS $S^{\mathrm{G} 13 \mathrm{D}}$ mutation. Therefore, they concluded that this composite tumor must have arisen by divergent cell differentiation from a CPC [74]. Zhang et al. [75] reported on a very unusual case of biphasic FL pro- gression presenting as a collision tumor consisting of an $\mathrm{H} / \mathrm{DC}$ sarcoma along with DLBCL in the hip of a 50 -yearold male who harbored an FL in the axillary LN. In this intriguing example of spatial and intratumoral heterogeneity, the authors could show that all 3 different tumors were clonally related by analysis for BCL2 rearrangement, and they concluded that both DLBCL and H/DC sarcoma had arisen from the FL clone [75]. On the other hand, Brunner et al. [76] provided elegant evidence for a CPC giving rise to FL and histiocytic sarcoma using fluorescence in situ hybridization (FISH) and array comparative genomic hybridization studies. In their case report, the histiocytic sarcoma clone contained a $t(14 ; 18)$ transloca- 
Table 2. Examples of transdifferentiation

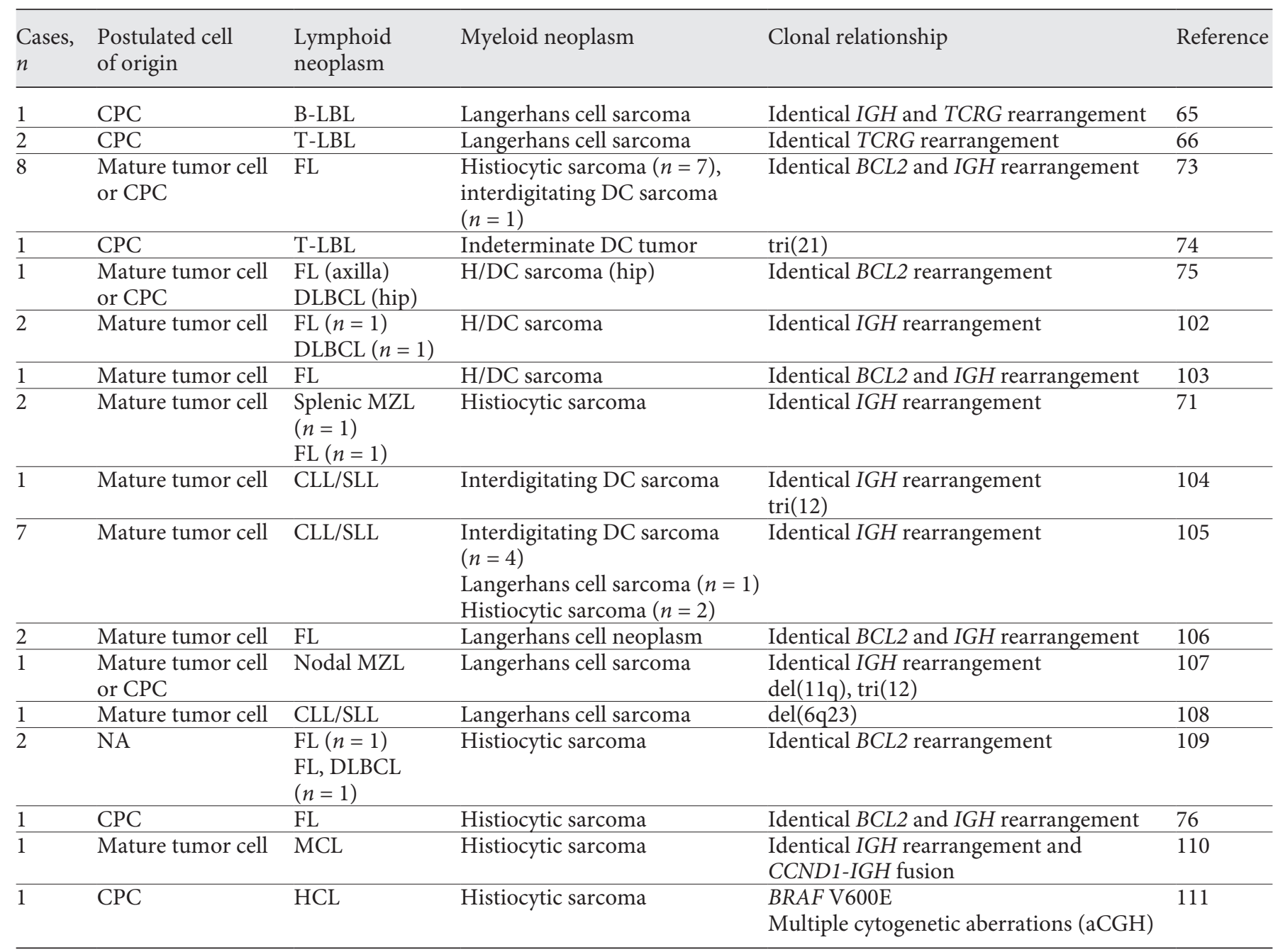

CPC, common progenitor cell/clone; NA, not applicable; B-LBL, B-cell lymphoblastic leukemia; T-LBL, T-cell lymphoblastic leukemia; FL, follicular lymphoma; DLBCL, diffuse large B-cell lymphoma; MZL, marginal zone lymphoma; CLL/SLL, chronic lymphocytic leukemia/small lymphocytic lymphoma; MCL, Mantle cell lymphoma; HCL, hairy cell leukemia; DC, dendritic cell; H, histocytic.

tion and clonal $I G H$ rearrangement identical to the FL clone; however, the FL clone had additional complex genetic changes detected by array comparative genomic hybridization that were not present in the histiocytic sarcoma, ultimately favoring the CPC hypothesis [76].

In summary, experimental and clinical evidence indicates that different mechanisms may lead to H/DC neoplasms in patients suffering from lymphomas, the most frequent one being transdifferentiation from mature tumor lymphocytes (Table 2). For future studies that investigate transdifferentiation, it is essential to properly address this issue using molecular techniques, either by physically separating the 2 tumor types via immune-directed laser capture microdissection or by morphologydirected FISH for chromosomal aberrations [64].

\section{Clinical and Radiological Implications of Tumor Heterogeneity in Lymphomas}

The morphologic, immunophenotypic, and molecular heterogeneity of lymphomas has a major influence on clinical practice and therapy decisions at different time points in the course of the disease. At first diagnosis, it is 
important to classify the lymphoma correctly because the best therapy for an individual patient can vary from "watch and wait" to multimodal (radio-, immuno-, and chemo-) therapy, depending on variables such as disease subtype, evidence for high-grade transformation, and various molecular risk factors [16-19].

As described above, disease heterogeneity may present as transformation from low- to high-grade lymphoma or as a second, clonally unrelated neoplasm. Clinical suspicion for transformation is based on rising serum lactate dehydrogenase levels, rapidly progressive lymphadenopathy, unexplained deterioration of the general condition, the appearance of B symptoms, or the development of extranodal disease [77]. Due to its prognostic relevance and impact on therapy decisions, high-grade transformation of low-grade B-NHL needs to be confirmed by a biopsy, since it can be mimicked by a variety of unrelated conditions. Because transformation can arise focally, selection of the best location for biopsy based on clinical findings and imaging studies is critical. In this context, ${ }^{18} \mathrm{~F}$-fluorodeoxyglucose positron emission tomography/computed tomography $\left({ }^{18} \mathrm{~F}-\mathrm{FDG}-\mathrm{PET} / \mathrm{CT}\right)$, which is routinely performed for clinical staging or reevaluation of lymphoma patients, can provide additional help [78, 79]. High standardized uptake values in ${ }^{18} \mathrm{~F}$-FDG-PET/CT correlate with high-grade histology and show a positive predictive value for transformed lymphoma. Therefore, high standardized uptake values in ${ }^{18} \mathrm{~F}$-FDG-PET/CT may guide the best site for biopsy [80-82]. In patients who cannot undergo invasive diagnostic procedures due to impaired coagulation, ${ }^{18} \mathrm{~F}-\mathrm{FDG}-\mathrm{PET} / \mathrm{CT}$ may corroborate a suspicion for relapse or high-grade transformation but does clearly not carry the same diagnostic weight as a tissue biopsy.

Another indication for a repeat biopsy is to demonstrate a potential change in the surface marker profile. As discussed above, the administration of rituximab can lead to a loss of CD20 expression on the neoplastic cells and/ or to increased plasma cell differentiation, which may require a modification of therapy.

The survival of patients with high-grade transformation of a preexisting low-grade HNL is generally worse as compared to patients with de novo high-grade disease, with a slight improvement in the era of rituximab. This inferior outcome is the result of both patient-specific and tumor-related factors, such as previous therapies, delayed hematopoietic recovery, and lower response rates after therapy on one hand and a more frequent presence of molecular risk factors and preselection of resistant clones on the other [82]. Patients with composite or transformed lymphomas are often excluded from clinical trials, and since standard therapies are lacking, current therapy concepts are highly individualized, with autologous or allogeneic hematopoietic stem cell transplantation as potential options in fit patients [33].

The current rapid advances in molecular diagnostics with the identification of novel genetic and epigenetic alterations, as well as an improved characterization of the tumor microenvironment have led to new insights into the pathogenesis of lymphoma and provide an opportunity for refined, biology-based treatments. However, the validation and integration of novel biomarkers in daily clinical practice and their translation into new treatment algorithms remains a challenge [83]. CLL/SLL is a paradigmatic disease in which molecular heterogeneity directly influences treatment decisions. In CLL/SLL, $\operatorname{del}(17 \mathrm{p})$ is associated with a worse prognosis and a resistance against fludarabine and alkylating agents. Mutations of the TP53 gene and an unmutated IGHV status are also associated with an adverse outcome, and these molecular alterations favor treatment decision towards high-intensity therapy with the use of novel agents like inhibitors of the B-cell antigen receptor signaling pathway such as ibrutinib or allogeneic hematopoietic stem cell transplantation in fit patients $[84,85]$.

\section{Concluding Remarks}

Personalized therapy for lymphoma patients requires precision diagnostics on all levels from molecular studies to radiological imaging. The current diagnostic gold standard still is histopathology; however, novel molecular developments will likely guide treatment decisions in the near future. The studies discussed in this review have provided important and invaluable insights into the genetic heterogeneity and pathogenesis of lymphomas, but knowledge about the genotypes in tumor cell clones at the single-cell level is still lacking. In addition, besides singlecell genome, epigenome, and transcriptome information, future investigations should include single-cell proteomes and metabolomes [86-94] and address the cells of the tumor microenvironment, like immune cell subsets. In addition, methods to analyze these parameters in situ in intact tissue will become crucial to investigate cellular localization and cell-cell interactions [95-99]. Computational integration of all these data in a so-called "cancer phenomics" approach will possibly guide future personalized medicine $[100,101]$. In conclusion, tumor heterogeneity in lymphomas will keep scientists, clinicians, and pathologists busy for time to come. 


\section{Acknowledgments}

C.M.S. was supported by a Clinical Medicine Plus Scholarship from the Prof. Dr. Max Cloëtta Foundation and the Uniscientia Foundation Vaduz. B.F. was supported by the TÜFF program of the University of Tübingen (project 2320-0-0).

\section{Author Contributions}

C.M.S. and F.F. conceived the review. C.M.S. drafted and wrote this paper and prepared the figures. B.F. wrote the clinical part and contributed histological photographs. All of the authors discussed and revised this paper and approved the final version.

\section{Disclosure Statement}

The authors declare that no conflict of interest exists.

\section{References}

1 Swanton C: Intratumor heterogeneity: evolution through space and time. Cancer Res 2012;72:4875-4882.

2 Ding L, Wendl MC, McMichael JF, Raphael BJ: Expanding the computational toolbox for mining cancer genomes. Nat Rev Genet 2014; 15:556-570.

3 McGranahan N, Swanton C: Biological and therapeutic impact of intratumor heterogeneity in cancer evolution. Cancer Cell 2015;27: 15-26.

4 Marusyk A, Polyak K: Tumor heterogeneity: causes and consequences. Biochim Biophys Acta 2010;1805:105-117.

5 Visvader JE: Cells of origin in cancer. Nature 2011;469:314-322.

6 Greaves M, Maley CC: Clonal evolution in cancer. Nature 2012;481:306-313.

7 Zhou H, Neelakantan D, Ford HL: Clonal cooperativity in heterogenous cancers. Semin Cell Dev Biol 2017;64:78-89.

8 Heppner GH, Miller BE: Tumor heterogeneity: biological implications and therapeutic consequences. Cancer Metastasis Rev 1983;2: 5-23.

9 Izzo F, Landau DA: Genetic and epigenetic determinants of B-cell lymphoma evolution. Curr Opin Hematol 2016;23:392-401.

10 Turke AB, Zejnullahu K, Wu YL, Song Y, Dias-Santagata D, Lifshits E, Toschi L, Rogers A, Mok T, Sequist L, Lindeman NI, Murphy C, Akhavanfard S, Yeap BY, Xiao Y, Capelletti M, Iafrate AJ, Lee C, Christensen JG, Engelman JA, Janne PA: Preexistence and clonal selection of MET amplification in EGFR mutant NSCLC. Cancer Cell 2010;17:77-88.

11 Keats JJ, Chesi M, Egan JB, Garbitt VM, Palmer SE, Braggio E, Van Wier S, Blackburn PR, Baker AS, Dispenzieri A, Kumar S, Rajkumar SV, Carpten JD, Barrett M, Fonseca R, Stewart AK, Bergsagel PL: Clonal competition with alternating dominance in multiple myeloma. Blood 2012;120:1067-1076.
12 Landau DA, Carter SL, Stojanov P, McKenna A, Stevenson K, Lawrence MS, Sougnez C, Stewart C, Sivachenko A, Wang L, Wan Y, Zhang W, Shukla SA, Vartanov A, Fernandes SM, Saksena G, Cibulskis K, Tesar B, Gabriel S, Hacohen N, Meyerson M, Lander ES, Neuberg D, Brown JR, Getz G, Wu CJ: Evolution and impact of subclonal mutations in chronic lymphocytic leukemia. Cell 2013;152:714-726.

13 Kreso A, Dick JE: Evolution of the cancer stem cell model. Cell Stem Cell 2014;14:275291.

14 Swerdllow SH, Campo E, Harris NL, Jaffe ES, Pileri SA, Stein H, Thiele J, Vardiman JW (eds): WHO Classification of Tumours of Haematopoietic and Lymphoid Tissues, ed 4. Lyon, IARC Press, 2008.

15 Swerdlow SH, Campo E, Pileri SA, Harris NL, Stein H, Siebert R, Advani R, Ghielmini M, Salles GA, Zelenetz AD, Jaffe ES: The 2016 revision of the World Health Organization classification of lymphoid neoplasms. Blood 2016;127:2375-2390.

16 Aguiar-Bujanda D, Blanco-Sanchez MJ, Jimenez-Gallego P, Mori-De Santiago M, Hernandez-Sosa M, Galvan-Ruiz S, Hernandez-Sarmiento S, Saura-Grau S, BohnSarmiento U: Therapeutic approaches in patients with newly diagnosed follicular lymphoma. Future Oncol 2014;10:1967-1980.

17 Kumar A, Sundararajan S, Puvvada S, Persky DO: Limited stage aggressive non-Hodgkin lymphoma: what is optimal therapy? Curr Treat Options Oncol 2016;17:45.

18 Gribben JG: How I treat CLL up front. Blood 2010;115:187-197.

19 Armitage JO: How I treat patients with diffuse large B-cell lymphoma. Blood 2007;110:2936.

20 Brudno J, Tadmor T, Pittaluga S, Nicolae A, Polliack A, Dunleavy K: Discordant bone marrow involvement in non-Hodgkin lymphoma. Blood 2016;127:965-970.

21 Agbay RL, Loghavi S, Medeiros LJ, Khoury JD: High-grade transformation of low-grade B-cell lymphoma: pathology and molecular pathogenesis. Am J Surg Pathol 2016;40:e1e16.
22 Parikh SA, Kay NE, Shanafelt TD: How we treat Richter syndrome. Blood 2014;123: 1647-1657.

23 Tsimberidou AM, Wierda WG, Plunkett W, Kurzrock R, O’Brien S, Wen S, Ferrajoli A, Ravandi-Kashani F, Garcia-Manero G, Estrov Z, Kipps TJ, Brown JR, Fiorentino A, Lerner S, Kantarjian HM, Keating MJ: Phase I-II study of oxaliplatin, fludarabine, cytarabine, and rituximab combination therapy in patients with Richter's syndrome or fludarabine-refractory chronic lymphocytic leukemia. J Clin Oncol 2008;26:196-203.

24 Rossi D, Spina V, Deambrogi C, Rasi S, Laurenti L, Stamatopoulos K, Arcaini L, Lucioni M, Rocque GB, Xu-Monette ZY, Visco C, Chang J, Chigrinova E, Forconi F, Marasca R, Besson C, Papadaki T, Paulli M, Larocca LM, Pileri SA, Gattei V, Bertoni F, Foa R, Young $\mathrm{KH}$, Gaidano G: The genetics of Richter syndrome reveals disease heterogeneity and predicts survival after transformation. Blood 2011;117:3391-3401.

25 Mao Z, Quintanilla-Martinez L, Raffeld M, Richter M, Krugmann J, Burek C, Hartmann E, Rudiger T, Jaffe ES, Muller-Hermelink HK, Ott G, Fend F, Rosenwald A: IgVH mutational status and clonality analysis of Richter's transformation: diffuse large B-cell lymphoma and Hodgkin lymphoma in association with B-cell chronic lymphocytic leukemia (BCLL) represent 2 different pathways of disease evolution. Am J Surg Pathol 2007;31: 1605-1614.

26 Ohno T, Smir BN, Weisenburger DD, Gascoyne RD, Hinrichs SD, Chan WC: Origin of the Hodgkin/Reed-Sternberg cells in chronic lymphocytic leukemia with “Hodgkin's transformation". Blood 1998;91:1757-1761.

27 Tsimberidou AM, O’Brien S, Kantariian HM, Koller C, Hagemeister FB, Fayad L, Lerner S, Bueso-Ramos CE, Keating MJ: Hodgkin transformation of chronic lymphocytic leukemia: the M. D. Anderson Cancer Center experience. Cancer 2006;107:1294-1302.

28 Montoto S, Fitzgibbon J: Transformation of indolent B-cell lymphomas. J Clin Oncol 2011;29:1827-1834. 
29 Chung R, Lai R, Wei P, Lee J, Hanson J, Belch AR, Turner AR, Reiman T: Concordant but not discordant bone marrow involvement in diffuse large B-cell lymphoma predicts a poor clinical outcome independent of the International Prognostic Index. Blood 2007;110: 1278-1282.

30 Sehn LH, Scott DW, Chhanabhai M, Berry B, Ruskova A, Berkahn L, Connors JM, Gascoyne RD: Impact of concordant and discordant bone marrow involvement on outcome in diffuse large B-cell lymphoma treated with R-CHOP. J Clin Oncol 2011;29:1452-1457.

31 Shim H, Oh JI, Park SH, Jang S, Park CJ, Huh J, Suh C, Chi HS: Prognostic impact of concordant and discordant cytomorphology of bone marrow involvement in patients with diffuse, large, B-cell lymphoma treated with R-CHOP. J Clin Pathol 2013;66:420-425.

32 Kremer M, Spitzer M, Mandl-Weber S, Stecker K, Schmidt B, Hofler H, Quintanilla-Martinez L, Fend F: Discordant bone marrow involvement in diffuse large B-cell lymphoma: comparative molecular analysis reveals a heterogeneous group of disorders. Lab Invest 2003;83:107-114.

33 Küppers R, Duhrsen U, Hansmann ML: Pathogenesis, diagnosis, and treatment of composite lymphomas. Lancet Oncol 2014; 15:e435-e446.

34 Fend F, Quintanilla-Martinez L, Kumar S, Beaty MW, Blum L, Sorbara L, Jaffe ES, Raffeld M: Composite low grade B-cell lymphomas with two immunophenotypically distinct cell populations are true biclonal lymphomas: a molecular analysis using laser capture microdissection. Am J Pathol 1999;154: $1857-1866$

35 Jaffe ES, Zarate-Osorno A, Kingma DW, Raffeld M, Medeiros LJ: The interrelationship between Hodgkin's disease and non-Hodgkin's lymphomas. Ann Oncol 1994;5(suppl 1):7-11.

36 Hoeller S, Copie-Bergman C: Grey zone lymphomas: lymphomas with intermediate features. Adv Hematol 2012;2012:460801.

37 Ejegod D, Sorensen KD, Mossbrugger I, Quintanilla-Martinez L, Schmidt J, Pedersen FS: Control of pathogenicity and disease specificity of a T-lymphomagenic gammaretrovirus by E-box motifs but not by an overlapping glucocorticoid response element. J Virol 2009;83:336-346.

38 Dogan A, Bagdi E, Munson P, Isaacson PG: CD10 and BCL-6 expression in paraffin sections of normal lymphoid tissue and B-cell lymphomas. Am J Surg Pathol 2000;24:846-852.

39 Eshoa C, Perkins S, Kampalath B, Shidham V, Juckett M, Chang CC: Decreased CD10 expression in grade III and in interfollicular infiltrates of follicular lymphomas. Am J Clin Pathol 2001;115:862-867.

40 Kampalath B, Barcos MP, Stewart C: Phenotypic heterogeneity of $B$ cells in patients with chronic lymphocytic leukemia/small lymphocytic lymphoma. Am J Clin Pathol 2003; 119:824-832.
41 Bilalovic N, Blystad AK, Golouh R, Nesland JM, Selak I, Trinh D, Torlakovic E: Expression of bcl-6 and CD10 protein is associated with longer overall survival and time to treatment failure in follicular lymphoma. Am J Clin Pathol 2004;121:34-42.

42 Soma LA, Craig FE, Swerdlow SH: The proliferation center microenvironment and prognostic markers in chronic lymphocytic leukemia/small lymphocytic lymphoma. Hum Pathol 2006;37:152-159.

43 Remstein ED, Hanson CA, Kyle RA, Hodnefield JM, Kurtin PJ: Despite apparent morphologic and immunophenotypic heterogeneity, Waldenstrom's macroglobulinemia is consistently composed of cells along a morphologic continuum of small lymphocytes, plasmacytoid lymphocytes, and plasma cells. Semin Oncol 2003;30:182-186.

44 Goteri G, Olivieri A, Ranaldi R, Lucesole M, Filosa A, Capretti R, Pieramici T, Leoni P, Rubini C, Fabris G, Lo Muzio L: Bone marrow histopathological and molecular changes of small B-cell lymphomas after rituximab therapy: comparison with clinical response and patients outcome. Int J Immunopathol Pharmacol 2006;19:421-431.

45 Seliem RM, Freeman JK, Steingart RH, Hasserjian RP: Immunophenotypic changes and clinical outcome in B-cell lymphomas treated with rituximab. Appl Immunohistochem Mol Morphol 2006;14:18-23.

46 Zenz T, Mertens D, Kuppers R, Dohner H, Stilgenbauer S: From pathogenesis to treatment of chronic lymphocytic leukaemia. Nat Rev Cancer 2010;10:37-50.

47 Parikh SA, Shanafelt TD: Prognostic factors and risk stratification in chronic lymphocytic leukemia. Semin Oncol 2016;43:233-240.

48 Landau DA, Tausch E, Taylor-Weiner AN, Stewart C, Reiter JG, Bahlo J, Kluth S, Bozic I, Lawrence M, Bottcher S, Carter SL, Cibulskis K, Mertens D, Sougnez CL, Rosenberg M, Hess JM, Edelmann J, Kless S, Kneba M, Ritgen M, Fink A, Fischer K, Gabriel S, Lander ES, Nowak MA, Dohner H, Hallek M, Neuberg D, Getz G, Stilgenbauer S, Wu CJ: Mutations driving CLL and their evolution in progression and relapse. Nature 2015;526:525530.

49 Chigrinova E, Rinaldi A, Kwee I, Rossi D, Rancoita PM, Strefford JC, Oscier D, Stamatopoulos K, Papadaki T, Berger F, Young KH, Murray F, Rosenquist R, Greiner TC, Chan WC, Orlandi EM, Lucioni M, Marasca $\mathrm{R}$, Inghirami $\mathrm{G}$, Ladetto $\mathrm{M}$, Forconi $\mathrm{F}$, Cogliatti S, Votavova H, Swerdlow SH, Stilgenbauer S, Piris MA, Matolcsy A, Spagnolo D, Nikitin E, Zamo A, Gattei V, Bhagat G, Ott G, Zucca E, Gaidano G, Bertoni F: Two main genetic pathways lead to the transformation of chronic lymphocytic leukemia to Richter syndrome. Blood 2013;122:2673-2682.
50 Fabbri G, Khiabanian H, Holmes AB, Wang J, Messina M, Mullighan CG, Pasqualucci L, Rabadan R, Dalla-Favera R: Genetic lesions associated with chronic lymphocytic leukemia transformation to Richter syndrome. J Exp Med 2013;210:2273-2288.

51 Okosun J, Bodor C, Wang J, Araf S, Yang CY, Pan C, Boller S, Cittaro D, Bozek M, Iqbal S, Matthews J, Wrench D, Marzec J, Tawana K, Popov N, O'Riain C, O'Shea D, Carlotti E, Davies A, Lawrie CH, Matolcsy A, Calaminici M, Norton A, Byers RJ, Mein C, Stupka E, Lister TA, Lenz G, Montoto S, Gribben JG, Fan Y, Grosschedl R, Chelala C, Fitzgibbon J: Integrated genomic analysis identifies recurrent mutations and evolution patterns driving the initiation and progression of follicular lymphoma. Nat Genet 2014;46:176-181.

52 Pasqualucci L, Khiabanian H, Fangazio M, Vasishtha M, Messina M, Holmes AB, Ouillette P, Trifonov V, Rossi D, Tabbo F, Ponzoni M, Chadburn A, Murty VV, Bhagat G, Gaidano G, Inghirami G, Malek SN, Rabadan R, Dalla-Favera R: Genetics of follicular lymphoma transformation. Cell Rep 2014;6:130 140 .

53 Green MR, Gentles AJ, Nair RV, Irish JM, Kihira S, Liu CL, Kela I, Hopmans ES, Myklebust JH, Ji H, Plevritis SK, Levy R, Alizadeh AA: Hierarchy in somatic mutations arising during genomic evolution and progression of follicular lymphoma. Blood 2013;121:16041611.

54 Alizadeh AA, Eisen MB, Davis RE, Ma C, Lossos IS, Rosenwald A, Boldrick JC, Sabet $\mathrm{H}$, Tran T, Yu X, Powell JI, Yang L, Marti GE, Moore T, Hudson J Jr, Lu L, Lewis DB, Tibshirani R, Sherlock G, Chan WC, Greiner TC, Weisenburger DD, Armitage JO, Warnke R, Levy R, Wilson W, Grever MR, Byrd JC, Botstein D, Brown PO, Staudt LM: Distinct types of diffuse large B-cell lymphoma identified by gene expression profiling. Nature 2000;403: 503-511.

55 Lenz G, Wright G, Dave SS, Xiao W, Powell J, Zhao H, Xu W, Tan B, Goldschmidt N, Iqbal J, Vose J, Bast M, Fu K, Weisenburger DD, Greiner TC, Armitage JO, Kyle A, May L, Gascoyne RD, Connors JM, Troen G, Holte H, Kvaloy S, Dierickx D, Verhoef G, Delabie J, Smeland EB, Jares P, Martinez A, LopezGuillermo A, Montserrat E, Campo E, Braziel RM, Miller TP, Rimsza LM, Cook JR, Pohlman B, Sweetenham J, Tubbs RR, Fisher RI, Hartmann E, Rosenwald A, Ott G, MullerHermelink HK, Wrench D, Lister TA, Jaffe ES, Wilson WH, Chan WC, Staudt LM; Lymphoma/Leukemia Molecular Profiling Project: Stromal gene signatures in large-B-cell lymphomas. N Engl J Med 2008;359:23132323.

56 O'Malley DP, Auerbach A, Weiss LM: Practical applications in immunohistochemistry: evaluation of diffuse large B-cell lymphoma and related large B-cell lymphomas. Arch Pathol Lab Med 2015;139:1094-1107. 
57 Hans CP, Weisenburger DD, Greiner TC, Gascoyne RD, Delabie J, Ott G, Muller-Hermelink HK, Campo E, Braziel RM, Jaffe ES, Pan Z, Farinha P, Smith LM, Falini B, Banham AH, Rosenwald A, Staudt LM, Connors JM, Armitage JO, Chan WC: Confirmation of the molecular classification of diffuse large B-cell lymphoma by immunohistochemistry using a tissue microarray. Blood 2004;103:275-282.

58 Scott DW, Wright GW, Williams PM, Lih CJ, Walsh W, Jaffe ES, Rosenwald A, Campo E, Chan WC, Connors JM, Smeland EB, Mottok A, Braziel RM, Ott G, Delabie J, Tubbs RR, Cook JR, Weisenburger DD, Greiner TC, Glinsmann-Gibson BJ, Fu K, Staudt LM, Gascoyne RD, Rimsza LM: Determining cell-oforigin subtypes of diffuse large B-cell lymphoma using gene expression in formalin-fixed paraffin-embedded tissue. Blood 2014;123: 1214-1217.

59 Quintanilla-Martinez L: IX. Is it only about MYC? How to approach the diagnosis of diffuse large B-cell lymphomas. Hematol Oncol 2015;33(suppl 1):50-55.

60 Jiang $\mathrm{P}$, Wang H, Li W, Zang C, Li B, Wong YJ, Meyer C, Liu JS, Aster JC, Liu XS: Network analysis of gene essentiality in functional genomics experiments. Genome Biol 2015;16: 239.

61 Juskevicius D, Lorber T, Gsponer J, Perrina V, Ruiz C, Stenner-Liewen F, Dirnhofer S, Tzankov A: Distinct genetic evolution patterns of relapsing diffuse large B-cell lymphoma revealed by genome-wide copy number aberration and targeted sequencing analysis. Leukemia 2016;30:2385-2395.

62 Shaknovich R, Melnick A: Epigenetics and Bcell lymphoma. Curr Opin Hematol 2011;18: 293-299.

63 Pan $\mathrm{H}$, Jiang $\mathrm{Y}$, Boi M, Tabbo F, Redmond D, Nie K, Ladetto M, Chiappella A, Cerchietti L, Shaknovich R, Melnick AM, Inghirami GG, Tam W, Elemento O: Epigenomic evolution in diffuse large B-cell lymphomas. Nat Commun 2015;6:6921.

64 Stoecker MM, Wang E: Histiocytic/dendritic cell transformation of B-cell neoplasms: pathologic evidence of lineage conversion in differentiated hematolymphoid malignancies. Arch Pathol Lab Med 2013;137:865-870.

65 Feldman AL, Minniti C, Santi M, Downing JR, Raffeld M, Jaffe ES: Histiocytic sarcoma after acute lymphoblastic leukaemia: a common clonal origin. Lancet Oncol 2004;5:248-250.

66 Feldman AL, Berthold F, Arceci RJ, Abramowsky C, Shehata BM, Mann KP, Lauer SJ, Pritchard J, Raffeld M, Jaffe ES: Clonal relationship between precursor T-lymphoblastic leukaemia/lymphoma and Langerhans-cell histiocytosis. Lancet Oncol 2005;6: 435-437.

67 Kondo M, Wagers AJ, Manz MG, Prohaska SS, Scherer DC, Beilhack GF, Shizuru JA, Weissman IL: Biology of hematopoietic stem cells and progenitors: implications for clinical application. Annu Rev Immunol 2003;21: 759-806.
68 Xie H, Ye M, Feng R, Graf T: Stepwise reprogramming of B cells into macrophages. Cell 2004;117:663-676.

69 Laiosa CV, Stadtfeld M, Xie H, de AndresAguayo L, Graf T: Reprogramming of committed $\mathrm{T}$ cell progenitors to macrophages and dendritic cells by C/EBP alpha and PU.1 transcription factors. Immunity 2006;25:731744.

70 Rapino F, Robles EF, Richter-Larrea JA, Kallin EM, Martinez-Climent JA, Graf T: $\mathrm{C} / \mathrm{EBP} \alpha$ induces highly efficient macrophage transdifferentiation of B lymphoma and leukemia cell lines and impairs their tumorigenicity. Cell Rep 2013;3:1153-1163.

71 Wang E, Hutchinson CB, Huang Q, Sebastian S, Rehder C, Kanaly A, Moore J, Datto M: Histiocytic sarcoma arising in indolent small B-cell lymphoma: report of two cases with molecular/genetic evidence suggestive of a "transdifferentiation" during the clonal evolution. Leuk Lymphoma 2010;51:802-812.

72 Wang E, Papalas J, Hutchinson CB, Kulbacki E, Huang Q, Sebastian S, Rehder C, Silbermins D, Moore J, Datto M: Sequential development of histiocytic sarcoma and diffuse large b-cell lymphoma in a patient with a remote history of follicular lymphoma with genotypic evidence of a clonal relationship: a divergent (bilineal) neoplastic transformation of an indolent B-cell lymphoma in a single individual. Am J Surg Pathol 2011;35:457463.

73 Feldman AL, Arber DA, Pittaluga S, Martinez A, Burke JS, Raffeld M, Camos M, Warnke R, Jaffe ES: Clonally related follicular lymphomas and histiocytic/dendritic cell sarcomas: evidence for transdifferentiation of the follicular lymphoma clone. Blood 2008;111: 5433-5439.

74 Buser L, Bihl M, Rufle A, Mickys U, Tavoriene I, Griskevicius L, Tzankov A: Unique composite hematolymphoid tumor consisting of a pro-T lymphoblastic lymphoma and an indeterminate dendritic cell tumor: evidence for divergent common progenitor cell differentiation. Pathobiology 2014;81:199-205.

75 Zhang D, McGuirk J, Ganguly S, Persons DL: Histiocytic/dendritic cell sarcoma arising from follicular lymphoma involving the bone: a case report and review of literature. Int $\mathrm{J} \mathrm{He}$ matol 2009;89:529-532.

76 Brunner P, Rufle A, Dirnhofer S, Lohri A, Willi N, Cathomas G, Tzankov A, Juskevicius D: Follicular lymphoma transformation into histiocytic sarcoma: indications for a common neoplastic progenitor. Leukemia 2014; 28:1937-1940.

77 Al-Tourah AJ, Gill KK, Chhanabhai M, Hoskins PJ, Klasa RJ, Savage KJ, Sehn LH, Shenkier TN, Gascoyne RD, Connors JM: Population-based analysis of incidence and outcome of transformed non-Hodgkin's lymphoma. J Clin Oncol 2008;26:5165-5169.
78 Barrington SF, Mikhaeel NG, Kostakoglu L, Meignan $M$, Hutchings $M$, Mueller SP, Schwartz LH, Zucca E, Fisher RI, Trotman J, Hoekstra OS, Hicks RJ, O’Doherty MJ, Hustinx R, Biggi A, Cheson BD: Role of imaging in the staging and response assessment of lymphoma: consensus of the International Conference on Malignant Lymphomas Imaging Working Group. J Clin Oncol 2014;32: 3048-3058.

79 Cheson BD, Fisher RI, Barrington SF, Cavalli F, Schwartz LH, Zucca E, Lister TA, Alliance AL, Lymphoma G; Eastern Cooperative Oncology Group; European Mantle Cell Lymphoma Consortium; Italian Lymphoma Foundation; European Organisation for Research; Treatment of Cancer/Dutch HematoOncology Group; Grupo Español de Médula Óseañ German High-Grade Lymphoma Study Group; German Hodgkin's Study Group; Japanese Lymphorra Study Group; Lymphoma Study Association; NCIC Clinical Trials Group; Nordic Lymphoma Study Group; Southwest Oncology Group; United Kingdom National Cancer Research Institute: Recommendations for initial evaluation, staging, and response assessment of Hodgkin and non-Hodgkin lymphoma: the Lugano classification. J Clin Oncol 2014;32:3059-3068.

80 Bodet-Milin C, Kraeber-Bodere F, Moreau P, Campion L, Dupas B, Le Gouill S: Investigation of FDG-PET/CT imaging to guide biopsies in the detection of histological transformation of indolent lymphoma. Haematologica 2008;93:471-472.

81 Noy A, Schoder H, Gonen M, Weissler M, Ertelt K, Cohler C, Portlock C, Hamlin P, Yeung HW: The majority of transformed lymphomas have high standardized uptake values (SUVs) on positron emission tomography (PET) scanning similar to diffuse large B-cell lymphoma (DLBCL). Ann Oncol 2009;20: 508-512.

82 Casulo C, Burack WR, Friedberg JW: Transformed follicular non-Hodgkin lymphoma. Blood 2015; 125:40-47.

83 Sun R, Medeiros LJ, Young KH: Diagnostic and predictive biomarkers for lymphoma diagnosis and treatment in the era of precision medicine. Mod Pathol 2016;29:1118-1142.

84 Stilgenbauer S, Schnaiter A, Paschka P, Zenz T, Rossi M, Dohner K, Buhler A, Bottcher S, Ritgen M, Kneba M, Winkler D, Tausch E, Hoth P, Edelmann J, Mertens D, Bullinger L, Bergmann M, Kless S, Mack S, Jager U, Patten $\mathrm{N}$, Wu L, Wenger MK, Fingerle-Rowson G, Lichter P, Cazzola M, Wendtner CM, Fink AM, Fischer K, Busch R, Hallek M, Dohner H: Gene mutations and treatment outcome in chronic lymphocytic leukemia: results from the CLL8 trial. Blood 2014;123:3247-3254.

85 Montserrat E, Dreger P: Treatment of chronic lymphocytic leukemia with del(17p)/TP53 mutation: allogeneic hematopoietic stem cell transplantation or BCR-signaling inhibitors? Clin Lymphoma Myeloma Leuk 2016;16:S74S81. 
86 Wang D, Bodovitz S: Single cell analysis: the new frontier in "omics". Trends Biotechnol 2010;28:281-290.

87 Smallwood SA, Lee HJ, Angermueller C, Krueger F, Saadeh H, Peat J, Andrews SR, Stegle O, Reik W, Kelsey G: Single-cell genome-wide bisulfite sequencing for assessing epigenetic heterogeneity. Nat Methods 2014; $11: 817-820$

$88 \mathrm{Xu}$ X, Hou Y, Yin X, Bao L, Tang A, Song L, Li F, Tsang S, Wu K, Wu H, He W, Zeng L, Xing M, Wu R, Jiang H, Liu X, Cao D, Guo G, Hu X, Gui Y, Li Z, Xie W, Sun X, Shi M, Cai Z, Wang B, Zhong M, Li J, Lu Z, Gu N, Zhang $\mathrm{X}$, Goodman L, Bolund L, Wang J, Yang H, Kristiansen K, Dean M, Li Y, Wang J: Singlecell exome sequencing reveals single-nucleotide mutation characteristics of a kidney tumor. Cell 2012;148:886-895.

89 Tang F, Lao K, Surani MA: Development and applications of single-cell transcriptome analysis. Nat Methods 2011;8:S6-S11.

90 Bendall SC, Nolan GP: From single cells to deep phenotypes in cancer. Nature Biotechnol 2012;30:639-647.

91 Spitzer MH, Nolan GP: Mass cytometry: single cells, many features. Cell 2016;165:780791.

92 Rubakhin SS, Lanni EJ, Sweedler JV: Progress toward single cell metabolomics. Curr Opin Biotechnol 2013;24:95-104.

93 Navin N, Hicks J: Future medical applications of single-cell sequencing in cancer. Genome Med 2011;3:31.

94 Shapiro E, Biezuner T, Linnarsson S: Singlecell sequencing-based technologies will revolutionize whole-organism science. Nat Rev Genet 2013;14:618-630.

95 Schubert W, Bonnekoh B, Pommer AJ, Philipsen L, Bockelmann R, Malykh Y, Gollnick $\mathrm{H}$, Friedenberger M, Bode M, Dress AW: Analyzing proteome topology and function by automated multidimensional fluorescence microscopy. Nat Biotechnol 2006;24:12701278 .
96 Gerdes MJ, Sevinsky CJ, Sood A, Adak S, Bello MO, Bordwell A, Can A, Corwin A, Dinn S, Filkins RJ, Hollman D, Kamath V, Kaanumalle S, Kenny K, Larsen M, Lazare M, Li Q, Lowes C, McCulloch CC, McDonough E, Montalto MC, Pang Z, Rittscher J, Santamaria-Pang A, Sarachan BD, Seel ML, Seppo A, Shaikh K, Sui Y, Zhang J, Ginty F: Highly multiplexed single-cell analysis of formalin-fixed, paraffin-embedded cancer tissue. Proc Natl Acad Sci USA 2013; 110:11982-11987.

97 Giesen C, Wang HA, Schapiro D, Zivanovic N, Jacobs A, Hattendorf B, Schuffler PJ, Grolimund D, Buhmann JM, Brandt S, Varga Z, Wild PJ, Gunther D, Bodenmiller B: Highly multiplexed imaging of tumor tissues with subcellular resolution by mass cytometry. Nat Methods 2014;11:417-422.

98 Angelo M, Bendall SC, Finck R, Hale MB, Hitzman C, Borowsky AD, Levenson RM, Lowe JB, Liu SD, Zhao S, Natkunam Y, Nolan GP: Multiplexed ion beam imaging of human breast tumors. Nat Med 2014;20: 436-442.

99 Rimm DL: Next-gen immunohistochemistry. Nat Methods 2014;11:381-383.

100 Zbuk KM, Eng C: Cancer phenomics: RET and PTEN as illustrative models. Nat Rev Cancer 2007;7:35-45.

101 Houle D, Govindaraju DR, Omholt S: Phenomics: the next challenge. Nat Rev Genet 2010;11:855-866.

102 Bassarova A, Troen G, Fossa A, Ikonomou IM, Beiske K, Nesland JM, Delabie J: Transformation of B cell lymphoma to histiocytic sarcoma: somatic mutations of PAX-5 gene with loss of expression cannot explain transdifferentiation. J Hematop 2009;2:135-141.

103 Zeng W, Meck J, Cheson BD, Ozdemirli M Histiocytic sarcoma transdifferentiated from follicular lymphoma presenting as a cutaneous tumor. J Cutan Pathol 2011;38: 999-1003.

104 Fraser CR, Wang W, Gomez M, Zhang T, Mathew S, Furman RR, Knowles DM, Orazi A, Tam W: Transformation of chronic lymphocytic leukemia/small lymphocytic lymphoma to interdigitating dendritic cell sarcoma: evidence for transdifferentiation of the lymphoma clone. Am J Clin Pathol 2009; 132:928-939.
105 Shao H, Xi L, Raffeld M, Feldman AL, Ketterling RP, Knudson R, Rodriguez-Canales J, Hanson J, Pittaluga S, Jaffe ES: Clonally related histiocytic/dendritic cell sarcoma and chronic lymphocytic leukemia/small lymphocytic lymphoma: a study of seven cases. Mod Pathol 2011;24:1421-1432.

106 West DS, Dogan A, Quint PS, Tricker-Klar ML, Porcher JC, Ketterling RP, Law ME, McPhail ED, Viswanatha DS, Kurtin PJ, Dao LN, Ritzer RD, Nowakowski GS, Feldman AL: Clonally related follicular lymphomas and Langerhans cell neoplasms: expanding the spectrum of transdifferentiation. Am J Surg Pathol 2013;37:978-986.

107 Ambrosio MR, De Falco G, Rocca BJ, Barone A, Amato T, Bellan C, Lazzi S, Leoncini L: Langerhans cell sarcoma following marginal zone lymphoma: expanding the knowledge on mature B cell plasticity. Virchows Arch 2015;467:471-480.

108 Chen W, Jaffe R, Zhang L, Hill C, Block AM Sait S, Song B, Liu Y, Cai D: Langerhans cell sarcoma arising from chronic lymphocytic lymphoma/small lymphocytic leukemia: lineage analysis and BRAF V600E mutation study. N Am J Med Sci 2013;5:386-391.

109 Fernandez-Pol S, Bangs CD, Cherry A, Arber DA, Gratzinger D: Two cases of histiocytic sarcoma with BCL2 translocations and occult or subsequent follicular lymphoma. Hum Pathol 2016;55:39-43.

110 Hure MC, Elco CP, Ward D, Hutchinson L, Meng X, Dorfman DM, Yu H: Histiocytic sarcoma arising from clonally related mantle cell lymphoma. J Clin Oncol 2012;30:e49e53.

111 Michonneau D, Kaltenbach S, Derrieux C, Trinquand A, Brouzes C, Gibault L, North MO, Delarue R, Varet B, Emile JF, Brousse $\mathrm{N}$, Hermine O: BRAF(V600E) mutation in a histiocytic sarcoma arising from hairy cell leukemia. J Clin Oncol 2014;32:e117e121. 